\title{
CAN LAW BE AN AGENT OF SOCIAL CHANGE?*
}

\author{
Dr. Murat ŞEKER
}

\section{Introduction :}

This paper will deal with two kinds of change; change in broad social processes, such as the division of labor, and change in law such as the importation of foreign codes as a replacement for religious law, in this case Moslem Sharia. The problem that this paper is meant to illuminate has to do with how the separation of spheres of changes for analytical purposes sometimes disturb the reality of the situation. While for analytical purposes we may separate social change from legal change, in fact we can not forget that the law is imbedded as part of the social process. Besides law, "all communities and societies acknowledge a mass of other rules of conduct -morality, custom etiquette, 'decent behavior'- many of which carry informal, often automatic sanctions". These rules "are not derived from laws; rather, rules normally becomle laws." (Stirling, 1957, 22). My main aim is to search if a law belonging to a completely different social structure can be an agent of social change when adopted to function in another social structure.

The situation that I describe for Turkey is a dynamic one, not amenable to the laboratory model, one in which the changes that are occuring in different parts of the social structure are occuring simultaneously and have resulted in reverberations which modify or contribute to change in other areas indirectly or with lag time. The situation I describe below covers a period of approximately $\mathbf{5 0}$ years, during which time in the legal saphere we see an official change from Moslem to Western law codes, and simultaneously the change in the society from rural self-sufficiency to a more fluid, urban oriented society.

* A similar paper was presented at the "Conference on Law and Development in the Contemporary Societies of the Middle East", on May 28th, 1983 at the University of California-Berkeley. 


\section{The Ottoman Legal and Social System:}

Important legal changes took place in the history of the Republic of Turkey in the mid-1920's. But Turkey, like many other contemporary reighbour states, has inherited a social system and a legal culture from the Ottoman Empire, due to the prior occupation of their lands by this state. The boundaries and their effects within the limitations of this diffusion have to be considered.

During the Turkish War of Liberation (1919-1923), in a remote village, an official was surrounded by a group of people. He asked them their identity. Were they Turks? "God forbid, no," was the answer; "We are Moslems." Noting that this was actually a Turkishspeaking village, we can begin to try to understand the culture and the social structure of the majority of the people at that time.

The main theme of governing the people of the Ottoman Empire was obedience to the rules of religion, that is, religion was the centerpiece of the State mechanism of the Ottoman Empire. The subjects were considered as "ummet" or the "flock of the religion." The sultan was also the caliph, and thus both their temporal and spiritual leader. The Sharia covered both the social and religious life. "In other words, Islamic Sharia is both divine and social." (Gökalp, 1959, 194). Thus in the Ottoman State, the Caesar's and God's belongings were united and the Judge, 'kadi' was also the highest religious authority.

As for the actual political powers of religion, we know that during the First World War the Sultan's Caliphacy did not affect the muslims beyond the borders. For that matter, we also know that the Caliphacy did not work as an effective political power within the State also, since there were many uprisings in Islamic communities. But setting apart the official state theory, we can say that the Caliph-Sultan and the Ummet relationship was effective when it was, not purely for religious reasons but also for being part of the culture of the society.

This society consisted mainly of small units of self-sufficient villages. Their relations with the outside warld consisted of paying taxes and sending their sons to the army, usally never to see them again. Industry was confined to handicrafts in the main body of the country and trade in the few harbour cities, both in the hands of non moslem people. The trade and the craftmanship were considered a dishonor by the State and no major official would 
wish to associate himself with such an occupation, thus ruling out one form of capital formation. And land ownership, being strictly under State control was to be ruled out too. Nobody or no family were left alone long enough to grow strong. enough to be a rival to the State. In the last years of the Empire, partly under foreign pressure, attempts were made to modernize parts of the society. These attempts (as the Gulhane and Tanzimat, declarations), as the following quotations illustrate, only 'created turmoil among the traditional and modern forces.

"The man who diagnosed the morbid nature, of this situation and recognized it as a major obstacle to progress towards the establishment of a modern state was Namik Kemal (1840-88). He attempted to show the orginal, or rather idealized, forms of the religious, moral, and legal institutions which were associated with Islam, and the original, or idealized, forms of the political institutions of the old Ottoman tradition at the time of its prime; and, at the same time, those aspects of civilization of the West which had given progress, prosperity, and superiority to the European nations. By his discussions of these three elements, he arrived at the conclusion that there were no basic contradictions among them. Islam according to him, would provide the moral and legal basis of society; the Ottoman tradition of statecraft, together with its multinational and multireligious cosmopolitan policy of toleration, would be the political framework of the Ottoman (not Turkish) state; and Western civilization would furnish the material and practical methods and techniques to enable this system to survive in the contemporary world of power and economic progress.

In this way Namik Kemal distinguished the areas of the three elements in the life of the nineteenth-century Turks. For him, the most important factor in the failure of Tanzimat was the mental confusion with regard to these three elements. Thus for example, the sheriat, the Islamic Law, was copped in order to take codes from France, while European methods in techniques of education, government, science, economy, and agriculture were not introduced. By their naive wish to modernize the state, the men of Tanzimat reforms unnecessarily undertook economic and political obligations towards European powers which robbed the Ottoman state of all independence and integrity. They did not apply any of the principles of modern democratic regimes in their administration. But neither the old Ottoman political institutions nor Muslim law were in reality incompatible with democracy and progress or with modern science. The main rasons why they were thought to be so were, first, the fact that all of these traditions had lost their original functions, and second, that the imposing penetration of European imperialism prevented their smooth adaptation. The Islamists and Westernists, as well as those interested in the Turkish masses and culture, were all Ottomanists at heart so far as political problems were concerned. Even the Young Turks, who were active in foreign countries beyond reach of the suppressive regime, were not clear on these issues. Only gradually and through 
discussion in party conventions, or through communications and publishing, did they come to ask the question: For what are we fighting? For a new Sultan? For a new constitutional Ottoman state which would guarantes the rights and privileges of the non-Muslim and non-Turkish communities of the empire? All of the Westernist Ottomanists were highly shocked when they were confronted with the nationalist demands of the representatives of these communities. For obvious reasons, none of them could admit nationalism either for their non-Muslim and non-Turkish colleagues or for themselves." (Berkes in Gökalp, 1959, 20)

The traditional forces within the Ottoman Society were opposed to change and the forces of modernization, as illustrated, did not have a national state in mind. The Union and Progress Party that came to power towards the end of the Ottoman State represented those forces of modernization and as we shall see differed from those of the New Turkish Republic.

\section{The Foundation of the Modern Turkish State :}

When' the new Turkish state was founded in Ankara and had to fight the War of Liberation, she had this Ottoman Empire against her. In fact it's fair to say that the founders of the Republic were actually fighting against the Ottoman Empire. The founders had sworn on and upon a "Misak-1 Milli", national oath, that the new state would include all, but only the Turks. They had the Union and Progress Party of the Ottoman Empire against them. For the founders of the Republic, the members of this party were guilty of, from forcing the State into war, to far eastern Pan-Turkist utopian adventures. The founders of the new state were extremely careful in keeping, even the defected members of the Union and Progress Party from the new state mechanism. ${ }^{*}$ Not surprisingly, all the leaders of the new state had all through the War of Liberation, the Ottoman Kadi's 'order of execution upon capture' pending upon them at all times. After the victory, the small Anatolian town of a few thousand, Ankiara, was kept as the capital of the new state and the leader, Atatürk, did not even visit Istanbul for years to come.

The functions of the new state also reflect this refusal. While in the Ottoman Empire the Parliament was completely under the powers of the administration, in the new state, the Parliament was the single source of power. The parliament not only made the laws

\footnotetext{
* Having spoken myself to one of the main figures, then in the State mechanism, Yakup Kadri Karaosmanoğlu, I can remember how he had still kept his anger towards the Istanbul Burocracy and the $U$. and $P \star$ Party in his ageing years.
} 
but also elected the officials, including the Priesident, and actually enforced the laws, and the army was called the Army of the Great National Assembly. The separation of powers was seen as a trick of the Union and Progress. On one occasion the Parliament came next to having the Prime Minister arrested for disobedience in a minor technical matter. This parliament abolished the Caliphacy. This parliament forbade the naming of the state as Islamic, and this parliament took over all the religious activities under a State directory. Thus, the once ruling Islam was now not even free but under strict State control. All the religious social and educational institutions were closed.

Later movements include unification of education under State control, adaptation of the Western calendar and the Latin Alphabet and the like. 1 mainly would like to investigate the adoptation of the Swiss Civil Code, which hit the people at first as a completely new law. This was part of the overall movement to Westernize the society.

\section{Socio-Economic Structures land Leglal Chainge's :}

The legal system in any country is part of the culture, and fits the society like an old dress. It is absurd to thinik that society, any society, can so be uprooted from its culture. In this context, how effective can drastic legal changes be; what conflicts result and what can a society do when it is confronted with such conflicts? In a similar international example although totally different in nature, we see that the Soviet penetration of Turkestan, in an effort to change the traditional legal system was widely opposed by the people of Turkestan (Massel, 1968, 179). Opposition can take many different forms, from ignorance to side stepping the issues, from a disturbance in the minds of the people to physical violence. Stirling argues that in the early fifties "in Turkey, as in many other instances,... the legislator has deliberately set out to alter the morality and custom of the people, and this not step by step, but by wholesale changes. But soon as the body of rules contained in the law ceases to be consistent with the informal system,... people will find the law unsatisfactory, and refrain from using it, thus... minimizing its social effects." (Stirling, 1957, 32).

I will now try to investigate the reactions of the people in such a period, and later the acceptance process trying to demonstrate the actual reasons of acceptance. For this I feel it necessary to work on 
the social history of modern Turkey. It is certainly impossible to confine social change to a certain time and it is very hard to landmark it. But still, to provide a basis for explanation, I shall examine the social-economical process in three periods; an introversive and stagnant 1923-1950 period, artificial capitalism of fifties, and the contemporary developments.

\section{A. 1923 to 1950}

During this period we see production mainly in a traditional fashion. Market-oriented production is minimal. The relationship of agricultural production to the gross National Product during this period varies very little; it is \% 39.8 in 1923 it becomes \% 45.3 in 1948. (Bulutay, 1974, 74). Production in small independent lands, as always, is apparently dominant, although large portions of land ownership exist, through sharecropping these are also actually a unity of small independent lands. Production is dependant on animal power and the single plow.

The landless and the small landowners who need to work, do so within traditional rules. They are sharecroppers paying for their rent in-kind and are under the social authority of the traditionalgreat-landowners (called Agas). The Aga himself has no way of utilizing his land other than this, due to lack of modern technology. There is no transportation, grain has to be imported from Romenia to feed Istanbul while it rots on the field in Central Anatolia because there is no market. Grain, the main food crop, is planted mainly for self consumption.

During the early years of the Republic, one of the Government's main income sources, 'Aşar' ( $\operatorname{tax}$ in kind) is canceled, but on the other hand the State starts to employ a grain purchase program. This, in the future is to help to control the market and the income of the producer.

In the early twenties the government hosts a Congress of Economics in Izmir. Representatives from all the imaginable sections of the society are called to this Conference. The discussions here are very important to shed light on both the structure of the period and the projections for the future. But to cut a long story short, the discussions dealt with the free private enterprise system and concerns about the inhuman side of capitalism; the strikes, lockouts, are rejected as it was thought they could not happen in this country "since the boss is going to be a Moslem like his workers 
and thus a father or a brother to them". Since' there was literally no one rich enough to undertake the task it falls upon the state to facilitate the formation of the new rich. Since money in traditional countries goes to speculation rather than production, buried rather than banked, the results are quite unsuccessful at the beginning.

Speculation does lead to some from of capital formation however and the second World War years (in peace for Turkey) do contribute to this concentration. To the end of the war the State was governed by the single party formed by the revolutionary bureauc rats who fought against the Ottoman Empire. Their unique class-like status helps them govern, but the new rich and the old landlords now free to gain power from the assaults of the Sultan were next in line. After the war, the bureaucracy made the last of a line of mistakes and introduced a land reform law. The law failed but it took less than four years for the new classes to form a party and win the elections. This brings us to the beginning of the new era.

During this first era the main body of population remained rural and isolated. Neither the economic nor the political structure was likely to lead to open participation nor to give any individual without inherited means, hope for untraditional ways of life. This was strongly reflected in the belief and set of actions of the people. The village is a unit; anybody else, even if he is from the neighboring village with the same set of beliefs, is a "foreigner". Gaining the trust of the villager is next to impossible for the technocrat who trys to bring innovations to the village. Any kind of State-Backed introduction into the village is feared ironically as a trick of the Ottoman.

Not surprisingly legal change was by no mean's welcome. "The people of the villages, towns and poorer parts of the cities who came together to fight against the Greeks and their supporters understood that they were fighting against the Rum, the Firenk, the infidels. They understood they were fighting to restore Sultian and Caliph to their rightful freedom, and political place. But,how many saw themselves as fighting for a Turkish nation? Or for'a secular liberal republic based on European laws and a European system of education?" (Stirling, 1981, 12).

First of all it is impossible to explain the vast legal changes, let alone enforce them on an isolated public. The villager can not easily understand what business the State has telling him that he can no longer have a second wife or that he can not overlook his daughters 
os his inheritors. In his eyes, the daughter is lost and out of the family when she gets married, and is it not ridiculous to leave some other family a part of his own property? Besides, did he not, as in the rules of Islam, spend the child's share during marriage for her? What shall happen to the property if her husband kicks her out? Try explaining to him that his daughter's husband will not be able to kick her out. How can she possibly exist, law or not, in a house in which she is not wanted?

This was the society and this was the understanding. Except for the very minor city population the Civil Code was almost totally ignored. And since the tool of the State in the village, the village headman, was also a village-elected person, prosecution for many was out of the question. The crimes against the Civil Code in this period are totally victimless, it is the same society the code is dealing with and the old customs, however illegal, are accepted by all. As in the case of the Soviet Turkestan official who keeps his wife at home and takes some other woman to a meeting with him to prove to the Party officials that he has accepted the new laws, it is much easier to oppose the law that to oppose the set of action and belief system of the society (Masel, 1978, 220). Thus, those who know of the new law or even those who believe in it can not do much about it.

The main source of introducing the new in this period was the army.' Every young man had to spend two years in the army. To utilize this fact, the army was turned into a school. New recruits were lined up and a half-naked man got dressed in front of them telling during the process what he was putting on. "This is called the trousers, this is a shirt, that is a tie" etc. The soldiers were taught the Latin alphabet. It was made into a challenge for them to be able to write home a letter instead of asking a clerk to take dictation. And when they were going home they were given a new set of modern clothing. Nevertheless the tie and the hat was always lost on the way.

Some aspects of the Civil Code were more vigorously enforced, however, especially when small children were involved. Marriage under a certain age was banned by the law and officials succeeded in making it a point to enforce this ban. The age limit could not be held as high as it was in the original draft and had to be lowered to fifteen, but no further ground was lost. But I believe success in this area was partly due to the participation of fathers 
not to let their daughters marry men too young to handle a wife, if not a family.

Primary school education was made obligatory and teachers were enforced with powers to seek out parents not obeying the rule. The understanding that girls do not need an education was sneered upon and many parents were dragged to court for such crimes. Even so, the boy and girl ratio of rural schools always stayed against the girls. When unable to keep older boys in school during harvest due to the high necessity of labor; the school calendar for rural areas was left more flexible.

Unequal treatment among sons somewhat decreased since they after all, had a tool of extortion, the threat to go to court, in their hands. While it was not acceptable in society for a daughter to go to court for inheritance, it was quite normal for a son to do so. This fear of the sons going to court started protecting the younger brothers against the elders. When rebellion among brothers occured, a side effect was that sisters started benefitting from it, since, when an inheritance was handled by the court it did not discriminate among the brothers and sisters.

In some other fields of law the changes were more effectively protected also. Secret religious schools were raided daily by the police and people running them heavily punished. The Dress Code was enforced by the police by capturing those who did not obey. When Weekend Code was passed, the police even arrested the leisure fishermen in the Bosphorous for working on a Sundey.

The Criminal Code of course can accept no sympathy when overlooked. A nationwide network of District Attorneys, Defenders of the Public (Rights), so called, were actively involved in enforcement and since they had powers over the police they had the tools. But the main changes in this area were methods of prosecution and degrees and kinds of punishment and were not ethical controversies, thus they were hardly subjects to be made into issues by the layman.

Some crimes were no longer crimes. It took some time to teach the people privacy, that you could not gather the neighborhood to hold a raid into the house of the unmarried woman who allegedly had a male visitor, nor could you inquire her wherabouts during a certain time, or have the right to stop her working at a certain place or hour. 
Although a crime in the Ottoman era too, reading the literature, I suspect that vengeance was sympathized with by the Sharia Judge. In the new Criminal Code however vengeance and blood feude were made a clause to increase the original penalty. Thus these kinds of crimes, while accepted and in some cases fed, flourished and caused by the society, were rigorously prosecuted by the D.A.

The main effective stream of thought of this period was nationalism. In every possible area the idea of being a nation was worked upon. It dan be said that, while for the first time in history the Republic of Turkey emerged without the name of her founder or founding group or family, also a real Turkish State was formed through the efforts of this period.*

With the emergence of an open society and a national identification, a new set of developments became inevitable. Here, I want to linger upon the development of labor and the legal aspects of the labor movements.

Some sort of a labor force both existed and was involved in labor movements even in the Ottoman era. But this was confined to few cities and small numbers. With the new state, and with the industrial program of the new state, labor came more self expressingly into existance.

Problems of labor and management were not altogether an expected phenomenon, as mentioned earlier. When these problems first emerged, they were thus seen as police cases caused by disturbed individuals.

The incidents grew into movements, however, and towands the end of the period we see unions and a federation of the unions coming into existence.

The main piece of adjudication to which I want to attract attention was the free collective bargaining rights with the power to strike for the workers. This was absent. It only existed in the programme of the new party of opposition, Democratic Party, which as told earlier was founded by the new class which owned the means but not yet the political power. This may seem controversive but I shall come to this point later.

- Stirling (1981) argues that this development took place after 1950. 


\section{B. 1950's to learly sixties.}

The Democratic Party's coming to power marks the beginning of this era. This party represented both the new rich and the traditional great land owners, with new ideas. After all, the talk of land reform had given rise to this party. Needless to say, the Democratic Party revealed that its first concern was agriculture.

Although its powers lay with the new rich, this party had succeeded in lighting up a fire of hope in the minds of many, not only for freedom from inevitable pressures of a bureaucratic government, from forced labor to taxes that ended in property confistications, but also for a new way of life. The leader of this party had said that their aim was to make "a Small America" out of the country.

During this period the land under tenure increased more than forty percent. Technology, mainly in shape of agricultural machinery bought from or given as aid from U.S.A. flooded the country. The optimum number of tractors for Turkey, calculated by World Bank experts in 1950 as 8000 , shortly surpassed this number many times over. (Singer, 1977, 199). The tractor became a;status symbol and an indicator of capital formation.

The sudden rush of technology created problems. Never before in the country's history had the "cultural lag" of technology been so great. But other than this, technology was also crippled for the lack of technology. There were not enough spare parts, not enough mechanics, not enough foundations to carry the technology. Moreover, mechanization increased the number of the poor living on city edges in urban areas and on forest and wasteland edges in rural. It is estimated that at its onset, mechanization caused the eviction of about 80.000 sharecropping families (Singer, 1977, 206). For this period, a World Bank expert, William $H$. Nicholls says that, only 25.000 to 27.000 families benefitted from the agricultural mechanization program.

This is also a period of International Companies moving into Turkey. These jointly with the new rich of trade and speculation were becoming new landmarks. A heavy highway program with the other effects, not only opened the country to the national but also to the international market.

A law that covered a field as important as the Civil Code, when it is effective singularly under state protection, it' is bound to start 
earning itself a base whether it is originally disliked or not. During this period the Civil Code thus is more and more effective due to increased information and decreased remembrance of the past.

More important than widened information about the Civil Code however is the recognizance of it as being much more effective in covering the "contracts" aspect of market-oriented production life. While traditionally one hand-shake or even an oral greement used to be enough, more and more bitter memories of these traditional methods bring people's attention to their rights and the ease of protecting them under the Civil Code.*

People moving from place to place for business or otherwise, the developing media coverage, improvement in education and one or two pioneer examples started an awareness of their rights in women. The urban areas led in this process but now due to immigration, the urban areas were much more in contact with the rural areas and the majority of the population. It is appropriate to say that at least the new immigrants still had one foot in the village, thus they became agents of innovation. Needless to say, the economical improvement in general, definitely made the father more concerned with the daughter. Thus, in this period it is almost exclusively the old marriages that had more than one wife.

The new government was highly dependant upon popular support since it had with such support done the impossible. And this government in search of uncostly political gains, found loosening the still unaccepted portions of the new legal system as an excellent weapon. It controlled the administration and the district attorneys but not the judges, because in passage of time, now the Parliament had eroded its control over the judiciary.

Working on whatever it had, it started by loosening the police pressure over religious schools and conventions, which we know are illegal; the teachers were less inclined to follow up upon absenteeism; the D.A. was less inclined to prosecute minor Dress Code violations.

The populist movement of the Democratic Party ended there, however. The right to strike for labor in their program was dropped as soon as they came to power. This was picked up and programmed now by none other than the old reigning party, the Republican

\footnotetext{
* Dr. S. Erel warns me that the old Islamic Code, the Mecelle, also had reasonable ordinances though only made for the "Hanefi" sect of Islam.
} 
People's Party. This will still seem controversive but I shall come to this.

The existing bureaucracy was ignored and even humiliated during this period. The bureaucracy's source of existence -rules, red tapes, regulations- were cast aside. An idiom, "due to apparent necessity" was developed by the government to fire bureaucrats without further reason. In fact, the government was so bold against the bureaucrats that it forgot that the army, part of this bureaucracy, had the guns.

The protest movement against this government started not with labor or the army, however, but from the universities. The army just stepped in to mark the end of this era. This is a temporary return to bureaucratic rule.

\section{c. 1960 to today.}

This period is marked by high political instability, returns and detours to and from democracy, but the economic powers prove that they are the actual policy makers as the bureaucracy gradually loses power and in my opinion for good. This marks the end of the unique example of a class like performlance of a 'bureaucracy for the world, except perhaps for the pending Soviet example.

It would be fair to say that during this time the free market system is settling down and the political turmoils are a result of this settlement.

It may yet be to early to try to understand the new era which started with a militiary takeover on Sept. 12th, 1981.' During this era the new Constitution of 1982 was put into effect. A new civilian government came to power after the general elections at the and of the year 1983 .

There has been a great deal of changes on the labor laws however. While the determination process of the trade unions in charge, in sectors and plants was put under tighter control, the types and places of work without the possibilities of strike have, been increased. In fact the possibility of strikes have been very much limited. Collective bargaining in many cases has become obedience to the results of the decisions of an arbitrary council.

It is going to be interesting to scholars of Sociology of Law to observe how these new changes will effect the labori in the future. 


\section{Conclusion}

I have tried to outline main features of the socio-legal history of contemporary Turkey. In doing so, I noted the various aspects of the Civil Code, as specifically related to gender, marriage and property. I also explained the seemingly circular action of the labor movement. Looking back on what I have written so far, it can have totally different meanings for different approaches. What. I want to do now is try to formulate what it means to me.

I want to start by distinguishing among the kinds of new laws introduced to a society.

The State Law : Some laws come, and sometimes out of the blue, from the state. The society has a very short notice. These laws are oriented to effeot the society in a certain direction.

The Popular Law: These laws are the results of a build-up in the society. The society feels the necessity for them and eventually public pressure makes them into laws. These laws are oriented to affect the State in a certain direction.

In both cases the effects expected from these laws are change or containment. Change and containment are not opposites but simply they show different degrees of effect.

Turkey's passing the Civil Code is an example of a state law. This was expected to Westernize the society. What actually does a law do to a society, or rather, can a law change a society? The answer to this question is : it sure can. If you ban a certain kind of dress and arrest those who wear it, nobody wears it, and it is a changed society. Or is it?

There were some things that the Civil Code changed at once in the Turkish Society and there were others it could not. The marriage age in the law was high, but it had to be lowered. The courts were full of cases demanding birthdate changes in their birth certificates. But then, as years passed on, this rule in the Code almost lost its significance. Religious marriages were limited to only legally married couples; in other words, you had to be legally married to be able to have a religious marriage ceremony. Nobody could enforce this law. Only time succeeded in enforcing this rule. Against the law, a man could find ways of having two wives, he would simply ignore the law, or if he cared at all, he could divorce, remarry and live with both wives. As long as the society and both women accepted 
this, which they did, nothing could be done. On the same subject Stirling writes;

"In the short run, these changes probably had limited effects. Of course, people with property and education were immediately affected. But the majority of people-four fifths were villagers, nine-tenths nonliterate- presumably did what the majority of posants in agrarian societies normally do -as my own field work experience in Turkey and in Italy confirm- they kept out of official trouble. Changes in the administrative arrangements and in the aims of the officials did not alter established attitudes to government. Government -in very general terms- is to be obeyed in 80 far as obedience is unavoidable; used to one's own advantage if the occasion arises; and otherwise ignored or kept at arm's length.

"As for the internal relations within communities -the day to day relations of families, kind, neighbours, sellers and buyers, employers and employed- these were very largely controlled by those tight community controls that I have emphasised. The strength of these controls did not of course inhibit quarrels. But it did provide ways of settling the most dangerous of them, and of living with unsettled disputes for long periods. What people did about establishing locally the propriety of marriages, and how they regulated the spouses' treatment of each other, were in most places not perceived as matters for the State at all; thay were arranged locallyi by local norms and local institutions, perceived as grounded in divine authority. Thus such revolutionary and all pervasive reforms were largely possible because the daily commonplaces of social order did not rest with the State but with local communities.

"Writers often list Atatŭrk's reforms; and we all admire his political skill in getting them through the Grand National Assembly, and praise his visions in initiating and enforcing such a sweeping programme of secularisation and rationalisation so swiftly, while the circumstances were so favourable.

"It is perhaps not unfair to claim that most educated people make the simple assumption that by and large what is law is what happens, giva or take a minor degree of resistance and deviance. What strikes me is that the fact that Atatürk's reforms were not only not the responsibility of a popular movement but were imposed on a society of small, tightly organised local communities whose whole perception of reality and whose customs and social organisation was at best tacitly inconsistent with, if not downright opposed to, these reforms. What is astonishing is that these reforms were not only enacted, they were in due time enforced, and except for relatively minor retreats on the severity of control of religious practices and religious education, they have survived intact. The laws in this case did not reflect the people's perceptions of social and ultimate reality, but were one major factor acting to change them. My main argument is that this achievement has in fact been underestimated." (Stirling, 1981, 14-15).

In the state law cases, the intent of the lawmakers is, as in the 
given Turkish example, progress for the society. We can say now that the law, to a degree, effects the society. Another phenomenon is, is this effect progress? Had there not been a Dress Code would Turky be worse than it is? Or had Sharia law survived, would the women be in a worse condition? The answer to these questions is not easy.

Social change in a society is a continium. So, we could have expected the Turkish society to achieve progress without the forced legal change. Besides, some of the examples are related to forms rather than substance in issues of development, as in the case of the Dress Code.

There are those, however, who think a society does need this kind of seemingly symbolic pushes. The idea behind this is that the law should guide rather than lag behind.

Although it worries me as to who is to decide how and where to lead a society and how this authority will have the right to do so, I also feel that some of the state laws I have talked about have been helpful.

Further pursuit of this discussion takes the matter more and more into the philosophy of law, which I do not want to pursue.

One of the first lessons of driving a car is that, there are different speeds for different gears. You can not drive 50 m.p.h. in first gear, nor can you drive 15 m.p.h. in fourth gear. Society resembles the united cups in Physics; similarly it has different bodies of different shapes but they are all united at one point. The law is only one of these bodies. When you pour water into one of these cups, it levels to become equal in all the cups. Similarly you can not push a certain part of a society to higher than where it belongs, you certainly can not, by using pressure in one section, hope to bring the society to a different point. What you do has an effect, a contained effect, just as big as it is and it will do that much, not more. The final level of water will show you where you are, as will the final say of the society. After the final say of the society. has been said, this will tell which gear you need not to burst or stall the engine. When you reach a different level of speed, depending on the road conditions, of course, the car will demand a higher gear. Popular law is a result of society's asking higher gear; state law is an early high gear. In all cases, every example is defferent, every society is unique, every time demands a different kind of action. 


\section{SHORT BIBLIOGRAPHY}

ABADAN-UNAT, Nermin. 'Türk Toplumunda Kadın', Türk' Sosyal Bilimler Derneğt Yayın, Ankara 1979.

BULUTAY, Tuncer, and others, Türkiye Milli Geliri, 1923-2848, AUSBFY., Ankara, 1977.

GOKALP, Ziya, 'Turkish Nationalism and Western Civilization', Greonwood Press. Conn., 1958. (Originally written before 1824).

SINGER, Morris, 'The Economic Advance of Turkey, 1838-1860'. Turkish Economic Society Publications, Ankara, 1977.

STIRLING, P., Land, Marriage, and the Law in Turkish Villages, International Social Science Bulletin, Vol IX. No. 1, 1857.

STIRLING, P., Social Change and Social Control in Republican Turkey, 1881, unpublished.

MASSEL, Gregory J., Law as an Instrument of Ravolutionary Change in a Traditional Milieu : The Case of Soviet Central Asia, Law and Society Studies, Vol II. nunber 2, 1878. 